\title{
Physicochemical Characteristics and Heavy Metal Levels in Soil Samples obtained from Selected Anthropogenic Sites in Abeokuta, Nigeria
}

\author{
*11OLAYINKA, OO; ${ }^{1}$ AKANDE, OO; ${ }^{1}$ BAMGBOSE, K; ${ }^{2}$ ADETUNJI, MT
}

\author{
${ }^{I}$ Department of Environmental Management and Toxicology, Federal University of Agriculture, Abeokuta \\ ${ }^{2}$ Department of Soil Science and Land Management, Federal University of Agriculture, beokuta \\ Corresponding Author: fummy2favor@yahoo.com.ph
}

\begin{abstract}
This study assessed the effect of heavy metals introduced into the soils through human activities which can bio-accumulate in plants and passed to man via the food chain that can pose health risk. Topsoil samples were collected from selected anthropogenic and control sites (dumpsites, mechanical workshops, abattoirs, fuel filling stations and hospital incinerators) in Abeokuta, Nigeria at the depths $0-5 \mathrm{~cm}, 5-10 \mathrm{~cm}$ and $10-15 \mathrm{~cm}$. Physicochemical parameters such as $\mathrm{pH}$, moisture content, bulk density, organic matter, organic carbon, particle size distribution and $\mathrm{Mn}, \mathrm{Zn}, \mathrm{Pb}$, and $\mathrm{Cd}$ were analyzed in soils using standard methods. Soil $\mathrm{pH}$ values ranged from $5.17-8.28$, moisture content ranged from $3.50-28.55 \%$, bulk density ranged from $0.78-2.29 \mathrm{gcm}^{-3}$, organic matter ranged from $0.09-16.01 \%$, organic carbon ranged from $0.02 \%-8.48 \%$. Mean concentrations of heavy metals $\left(\mathrm{mgkg}^{-1}\right)$ ranged from $182.69 \pm 61.95$ $697.06 \pm 85.62 ; 122.69 \pm 30.04-632.94 \pm 508.79 ; 19.38 \pm 6.72-158.50 \pm 71.41 ; 0.25 \pm 0.00-1.63 \pm 1.38$ for Mn, $\mathrm{Zn}, \mathrm{Pb}$ and $\mathrm{Cd}$ respectively. Distribution pattern of heavy metals in petrol stations, abattoirs, mechanic workshops and hospital incinerator sites were $\mathrm{Mn}>\mathrm{Zn}>\mathrm{Pb}>\mathrm{Cd}$, while for dumpsites $\mathrm{Zn}>\mathrm{Mn}>\mathrm{Pb}>\mathrm{Cd}$. Pollution index indicated that soil qualities varied between slightly contaminated to severely polluted status. This showed that the heavy metal contamination of the soils does not call for any alarm; proactive measures must be taken to minimize accumulation of these metals. CJASEM

https://dx.doi.org/10.4314/jasem.v21i5.14
\end{abstract}

Keywords: Heavy metals, dumpsites, pollution, physicochemical parameters, abattoirs and soils

Heavy metals are released into the environment by both natural and anthropogenic sources. The main natural sources of metals in soils are chemical weathering of mineral; the anthropogenic sources are associated mainly with industrial, agricultural, mining, land disposal of waste, waste incineration, mechanic workshop and fuel filling station (Fernando et al., 2012). Heavy metals contamination of topsoil has been a major concern regarding their toxicity, persistence and non-degradability in the environment. Toxicity of these compounds has been reported extensively (Momodu and Anyakora, 2010; Anyakora et al, 2011). They accumulate overtime in soils, which act as a sink from which these toxicants are released to the groundwater and plants and end up through the food chain thereby causing various toxicological effects. Effects of elevated concentrations of heavy metals to soil functions, soil microbial composition and microbial growth have long been reported under both field and laboratory condition (Tyler et al, 1989). Health effect of elevated levels of $\mathrm{Zn}$ are severe vomiting, diarrhoea, bloody urine, liver, kidney failure and anaemia (Fosmire, 1990), while excessive $\mathrm{Pb}$ poison causes inhibition of haemoglobin synthesis, dysfunction in the kidneys, reproductive systems and cardiovascular system (Ferner, 2001). Other effects of $\mathrm{Pb}$ poison are damage to gastro-intestinal system, mental retardation in children, abnormalities in fertility and pregnancy (Dara, 2000). Excess $\mathrm{Cd}$ have being reported to bring about renal dysfunction, anaemia, hypertension, bone marrow disorder, cancer, kidney damage, bronchitis, liver and brain disorder (Dara, 2000), while, high concentration of manganese could results in kidney failure, liver and pancreases malfunctioning (Underwood, 1977). Human activities in urban areas largely contribute to the contamination of urban soils and this is a major health concern. Iwegbu et al., (2006) reported elevated concentration of $\mathrm{Cd}, \mathrm{Cr}, \mathrm{Cu}, \mathrm{Pb}, \mathrm{Ni}$, and $\mathrm{Zn}$ in an automobile mechanic workshop soil while Dauda and Odoh, (2012) in their study revealed the high degree of contamination of $\mathrm{Pb}, \mathrm{Cd}$ and $\mathrm{Zn}$ in soil from fuel filling stations in Benue state. In addition, Ubwa et al., 2013 reported high levels of $\mathrm{Cd}, \mathrm{Zn}, \mathrm{Ni}, \mathrm{Cr}$ and $\mathrm{Pb}$ from soil around the Gboko Abattoir. The extent of human impact is now so pervasive and profound, that there is need to investigate the levels of heavy metals in soils from different anthropogenic sites. The objective of this study is to determine the physicochemical characteristics and heavy metals in surface and sub-surface soil samples from control sites and selected anthropogenic sites (dumpsites, mechanical workshops, abattoirs, fuel filling stations and hospital incinerators) in Abeokuta, Nigeria.

\section{MATERIALS AND METHODS}

Description of study area: Abeokuta is the capital of Ogun State, southwestern Nigeria. It is situated between latitudes $7^{\circ} 6^{\prime} \mathrm{N}$ to $7^{\circ} 13^{\prime} \mathrm{N}$ and longitudes $3^{\circ} 16^{\prime} \mathrm{E}$ to $3^{\circ} 25^{\prime} \mathrm{E}$ on the east bank of the Ogun River, around a group of rocky outcroppings that rise above 
the surrounding wooded savanna (Hoiberg, 2010). The city is situated $81 \mathrm{~km}$ south-west of Ibadan and $106 \mathrm{~km}$ north of Lagos with population of 593,100 by World Population Reviewed (WPR, 2015). Abeokuta is within the rain forest zone of Nigeria: and enjoys a tropical climate with distinct wet and dry seasons with dry period of about 130 days (Orebiyi et al. 2008). It has a high population density of more than 500 persons per hectare. The population have continue to grow making the city to sprawl toward surrounding villages and smaller towns such as Ajebo, Osiele, Odeda, Imala, Aro to mention a few.

Samples collection and Preparation: Sampling locations were selected based on anthropogenic activities; such as dumpsites, abattoirs, mechanic workshops, petrol stations, hospital incinerator sites and soil samples collected from the same sources in Abeokuta city and also from two control sites (uncultivated forest and lawn) in Federal University of Agriculture Abeokuta.

Samples were collected at different depths $(0-5 \mathrm{~cm}$, $5-10 \mathrm{~cm}, 10-15 \mathrm{~cm}$ ) using soil auger and transferred into cellophane bags, tightly sealed with minimal air space and labelled with carbon free paper outside and stored in a cool place to prevent breaking down of organic matter. Samples were air dried for 48 hours, and then sieved with $2 \mathrm{~mm}$ mesh to remove debris, gravel and other materials prior to analysis.

Soil Analysis: Determination of $\mathrm{pH}\left(\mathrm{H}_{2} \mathrm{O}\right)$ : The $\mathrm{pH}$ of soil samples was determined according to Bamgbose et al. (2000). 10 grams of the air dried sample were weighed into $100 \mathrm{ml}$ beaker and $20 \mathrm{ml}$ of distilled water was added. The mixture was allowed to stand for 30minutes with occasional stirring with glass rod. The electrode of calibrated $\mathrm{pH}$ meter (Horiba $\mathrm{pH}$ meter D-51) was inserted into the partially settled suspension and the $\mathrm{pH}$ of the soil was measured.

Determination of Bulk Density: Bulk density was determined according to the method of Hunt and Gilkes, (1992) adopted by Mckenzie et al. (2004). Samples were collected by coring, where a thinwalled metal cylinder of known volume $(\mathrm{V})$ was pushed into the soil at right angles to ground surface. The cylinder was then dug out and the soil core was gently pushed out of the cylinder using a plunger, into a cellophane bag and transported to the laboratory where it was oven-dried at $105^{\circ} \mathrm{C}$ and weighed as (M).

Bulk density $=\underline{\text { mass of the sample }(\mathrm{M})(\mathrm{g})}$ Volume of the tin $(\mathrm{V})\left(\mathrm{cm}^{3}\right)$
Moisture Content: The moisture content of the soil is an indication of the amount of water present in the soil. It was determined according to the method described by Anderson and Ingram (1989). 1g of a representative sample of the soil was placed in a clean dry crucible of known mass. The mass of the container and soil were determined $\left(\mathrm{W}_{2}\right)$ using an analytical balance (OHAUS Advance AR 3130 Model). The crucible was placed in an oven maintained at $110 \pm 5^{\circ} \mathrm{C}$ for 4 hours to obtain a constant weight $\left(\mathrm{W}_{1}\right)$. The measurement was done in duplicate. \% Moisture was calculated as follows:

$\%$ Moisture $=\left(\mathrm{W}_{2}-\mathrm{W}_{1}\right) /$ Sample weight; Where $\mathrm{W}_{2}$ = weight of crucible + weight of sample before oven drying; $\mathrm{W}_{1}=$ weight of crucible + weight of sample after oven drying.

Particle size Analysis: Particle size analysis was determined according to the method of Bouyoucos (1962). $50 \mathrm{~g}$ of the soil sample was soaked overnight with $50 \mathrm{ml}$ of cagon solution. The mixture was then transferred into a $1000 \mathrm{ml}$ measuring cylinder and was made up to mark. The mixture was shaken and left for 40 secs. before dipping the hydrometer into it to determine the sandy content while the clay and silt was determined after 3 hours interval (for the mixture to settle down) through the same process. The temperatures were then recorded simultaneously. $\%$ sand, $\%$ clay and $\%$ silt were calculated as follows where $\mathrm{H}_{1}$ and $\mathrm{H}_{2}$ are hydrometer readings at 40 secs and 3 hours respectively at corresponding temperature readings $T_{1}$ and $T_{2}$ :

$$
\begin{aligned}
& \% \text { sand }=100-\left[H_{1}+0.2\left(T_{1}-68\right)-2.0\right]^{2} \\
& \% \text { clay }=\left[H_{2}+0.2\left(T_{2}-68\right)-2.0\right]^{2} \\
& \% \text { slit }=100-(\% \text { sand }+\% \text { clay })
\end{aligned}
$$

Determination of Organic Carbon: The organic carbon content of soils was determined by the Walkey- Black and digestion method as described by Anderson and Ingram (1989). About $1 \mathrm{~g}$ of soil sample was placed into a block digester tube (sample weight) and added $5 \mathrm{ml}$ of potassium dichromate solution and $7.5 \mathrm{ml}$ of concentrated $\mathrm{H}_{2} \mathrm{SO}_{4}$. The tube was placed in a pre- heated block at $145-155{ }^{\circ} \mathrm{C}$ for 30 minutes, then removed and allowed to cool. The digest was quantitatively transferred into a $100 \mathrm{ml}$ conical flask and then added $0.3 \mathrm{ml}$ of $\mathrm{O}$ phenanthrene- ferrous complex (ferroin) indicator solution, then stirred and mixed properly using magnetic stirrer. The digest was titrated with ferrous ammonium sulphate solution with end point 
indicating a change from greenish to brown colouration. The organic carbon content expressed in percentage as follows was based on $77 \%$ recovery factor

$\%$ Organic $\mathrm{C}=\frac{N(T-B)}{W} \times 0.390$

Where $\mathrm{N}=\quad$ Normality of $\mathrm{KMnO}_{4} ; \quad \mathrm{T}=$ Volume of $\mathrm{KMnO}_{4}$ used in titration of soil; $\mathrm{B}=$ Volume of $\mathrm{KMnO}_{4}$ used in titration of blank; and $\mathrm{W}$ $=$ Weight of soil in gram

Determination of trace elements ( $\mathrm{Zn}$ and $\mathrm{Mn}$ ): $5 \mathrm{~g}$ of the dried sieved soil was digested with $\mathrm{HNO} 3-\mathrm{HCl}$ according to USEPA method $3050 \mathrm{~B}$ to extract the metals. The concentrations of $\mathrm{Zn}$ and $\mathrm{Mn}$ were measured by Perkin-Elmer Analyst 300 atomic absorption spectrophotometer (AAS).

Determination of soil $\mathrm{Pb}$ and $\mathrm{Cd}$ : $\mathrm{Ni}$ and $\mathrm{Cd}$ in the soil were determined according to the method of Ideriah et al., 2007. Exactly $0.2 \mathrm{~g}$ of the soil sample was weighed and $6 \mathrm{ml}$ freshly prepared aqua-regia (1:3) HNO3: $\mathrm{HCl}$ respectively was added and allowed to stand overnight and placed in a digestion block for about 30mins. It was allowed to cool and then filtered into a $100 \mathrm{ml}$ volumetric flask with distilled water. The filtrate was analyzed for selected heavy metals using Perkin-Elmer Analyst 300 atomic absorption spectrophotometer (AAS).

Contamination/Pollution Index $(C / P)$ of the Metals: The Contamination/Pollution Index $(\mathrm{C} / \mathrm{P})$ of the metals in the soils was calculated using the scheme formulated by Lacatusu, 2000.

$C / P=\frac{\text { Concentrat ion of the Metals in the Soil }}{\text { Target Value }}$

The target value was obtained by using the standard formulated by the Department of Petroleum Resources of Nigeria (DPR)/cluster abundant values for maximum allowed concentrations of heavy metals in soil in $\mathrm{mgkg}^{-1}$ (Pb: 85, Mn: 437, Zn: 146, Cd: 0.8). Contamination/Pollution Index value greater than 1, defines pollution range, but when it is less than 1, it defines contamination range (Lacatusu, 2000) Table 1.

Statistical Analysis: Results obtained from all samples were subjected to descriptive (mean, standard deviation and ranges) and inferential (ANOVA) statistics and $\mathrm{P}<0.05$ was considered to indicate statistical significance. Means were separated using Duncan's Multiple Range Test.

\section{RESULTS AND DISCUSSION}

Physicochemical Characteristics of Soil samples
Mean soil $\mathrm{pH}$ in dumpsites was $7.13 \pm 0.94,7.38 \pm 0.72$ and $7.24 \pm 0.83$ for $0-5 \mathrm{~cm} 5-10 \mathrm{~cm}$ and $10-15 \mathrm{~cm}$ depth respectively (Table 2 ), while in the abattoir it was $6.65 \pm 0.98,6.87 \pm 0.47$ and $6.74 \pm 0.74$ for $0-5 \mathrm{~cm}$, $5-10 \mathrm{~cm}$ and $10-15 \mathrm{~cm}$ depth respectively (Table 3). Soils taken from the fuel filling station had $\mathrm{pH}$ of $7.01 \pm 0.49,6.95 \pm 0.35$, and $6.98 \pm 0.49$ at depths of $0-5$ $\mathrm{cm}, 5-10 \mathrm{~cm}$ and $10-15 \mathrm{~cm}$ (Table 4). Soil samples from selected mechanic workshop showed mean $\mathrm{pH}$ values of $6.70 \pm 0.97,6.58 \pm 1.35$ and $6.48 \pm 1.43$ respectively (Table 5). Average $\mathrm{pH}$ values of the soil sample at hospital incinerator sites at depths $0-5 \mathrm{~cm}$, $5-10 \mathrm{~cm}$ and $10-15 \mathrm{~cm}$ were $6.69 \pm 0.21,6.59 \pm 0.33$ and $6.59 \pm 0.24$ respectively (Table 6). Soil $\mathrm{pH}$ values observed in this study were slightly acidic and neutral as indicated by Benton, (2002). Mean pH values obtained for mechanic workshops, dumpsites, hospital incinerators, and petrol stations at all depths were classified as slightly acidic and neutral which agreed with Dauda and Odoh (2012). The highest mean $\mathrm{pH}$ value was observed at abattoir sites at depth $0-5 \mathrm{~cm}$ while lowest at $10-15 \mathrm{~cm}$ depth, the range value was slightly acidic. The $\mathrm{pH}$ values in this study were lower than those values reported by Osakwe (2014), Farombi et al. (2013) and Jintao et al. (2011). Average $\mathrm{pH}$ values for all sites were lower than control sites (Table 7). Low $\mathrm{pH}$ from these anthropogenic sites could be as a result of the decomposition of organic matter that releases carbon (iv) oxide which reacts with water to for carbonic acid which eventually reduces soil $\mathrm{pH}$. This low $\mathrm{pH}$ enhances solubility and mobility of heavy metals (Akan et al., 2013) and the presence of humic acid which is the major acid in soil organic matter. Heavy metal mobility decreases with increasing soil $\mathrm{pH}$, hence most of the sites with low $\mathrm{pH}$ had relatively high concentration of selected heavy metals. Generally, soil moisture content varied between 6.84 $\%-21.89 \%$. In the dumpsite soil, average moisture were $16.11 \pm 1.49 \%$ in $0-5 \mathrm{~cm}$ depth, $17.89 \pm 7.27 \%$ in $5-10 \mathrm{~cm}$ depth, and $18.38 \pm 7.34 \%$ in $10-15 \mathrm{~cm}$ depth. Soil moisture content in the abattoirs varied with depth having $21.89 \pm 7.65,17.61 \pm 4.07$, and $19.50 \pm 6.62 \%$ at $0-5 \mathrm{~cm}, 5-10 \mathrm{~cm}$ and $10-15 \mathrm{~cm}$ respectively. The percentage soil moisture content in mechanic workshop was $10.19 \pm 4.65 \%, 11.18 \pm 7.06$ $\%$ and $7.90 \pm 4.39 \%$ at depths $0-5 \mathrm{~cm}, 5-10 \mathrm{~cm}$ and $10-15 \mathrm{~cm}$ respectively. Soil moisture contents were found to vary with depths, which was similar to report of Wakene (2001) and this may be due to the amount of clay (Andrade et al. 2011) and nature of the activities on the sites. The values of moisture content observed at control sites at all depths were similar to the report of Gebeyaw (2007). Bulk density values in dumpsites ranged from $1.31 \pm 0.28$ $\mathrm{gcm}^{-3}$ to $4.47 \pm 0.12 \mathrm{gcm}^{-3}$. Furthermore, bulk density 
ranged from $1.16 \pm 0.30 \mathrm{gcm}^{-3}$ to $1.81 \pm 0.37 \mathrm{gcm}^{-3}$ across the depths in abattoirs. Bulk density ranged from $1.37 \pm 2.00$ to $1.49 \pm 0.13 \mathrm{gcm}^{-3}$ in fuel filling stations. Bulk density was highest at dumpsites at depth of 0-5 cm and lowest value obtained at hospital incinerator sites and control (forest/lawn) sites. Soil compaction resulting from different anthropogenic activities on the sites may have caused the relatively higher bulk density. The values of bulk density were below mean value of $2 \mathrm{gcm}^{-3}$ reported by Onwermadu et al. (2007), except for the $4.47 \pm 0.12 \mathrm{gcm}^{-3}$ recorded in dumpsite soil at $0-5 \mathrm{~cm}$ depth, but agreed with the report of Jintao et al. (2011). The reason for the low values at depths $0-5 \mathrm{~cm}$ and $5-10 \mathrm{~cm}$ at some of the sites could be due to low or less disturbance on the sites. Bulk density values obtained in this study were within the ranges expected in most mineral soils as indicated by Mbagwu (2003). High bulk density $\left(>1.5 \mathrm{gcm}^{-3}\right)$ reduces water infiltration and plant root penetration resulting in increased surface water pollution (Ahmed, 2002). Particle size distribution at $0-5 \mathrm{~cm}$ showed $66.98 \pm 13.77 \%$ of sand, $25.28 \pm 11.96$ $\%$ of silt and $7.75 \pm 3.22 \%$ of clay in mechanic workshops. While, in hospital incinerators soil showed $48.25 \pm 3.53 \%$ for sand, $3.13 \pm 0.46 \%$ for clay and $48.25 \pm 4.33 \%$ for silt at depth $0-5 \mathrm{~cm}$. Particle

\begin{tabular}{|c|c|c|}
\hline$<$ C.PI & Significance & Remark \\
\hline$\overline{0.1}$ & $\begin{array}{l}\text { Very slight } \\
\text { contamination }\end{array}$ & No negative effect on soil, plant and environment \\
\hline $\begin{array}{l}0.10- \\
0.25\end{array}$ & $\begin{array}{l}\text { Slight } \\
\text { contamination }\end{array}$ & \\
\hline $\begin{array}{l}0.26- \\
0.5\end{array}$ & $\begin{array}{l}\text { Moderate } \\
\text { contamination }\end{array}$ & \\
\hline $0.5-$ & $\begin{array}{l}\text { Severe } \\
\text { contamination }\end{array}$ & \\
\hline $\begin{array}{l}0.76- \\
1.00\end{array}$ & $\begin{array}{l}\text { Very severe } \\
\text { contamination }\end{array}$ & \\
\hline $1.1-2.0$ & Slight pollution & Will pose negative effect on soil, plant and environment \\
\hline 2.1-4.0 & Moderate pollution & \\
\hline $4.1-8.0$ & Severe pollution & \\
\hline $\begin{array}{l}8.1- \\
16.0\end{array}$ & $\begin{array}{l}\text { Very severe } \\
\text { pollution }\end{array}$ & \\
\hline$>16.0$ & Excessive pollution & \\
\hline
\end{tabular}

Table 1: Interval of contamination/pollution index of heavy metals in soil and its significance

\begin{tabular}{lcll}
\hline Depth $(\mathbf{c m})$ & $\mathbf{0 - 5}$ & $\mathbf{5 - 1 0}$ & \multicolumn{1}{c}{$\mathbf{1 0 - 1 5}$} \\
\hline $\mathbf{p H}$ & $7.10 \pm 0.4^{\mathrm{b}}$ & $7.38 \pm 0.72^{\mathrm{a}}$ & $7.24 \pm 0.3^{\mathrm{b}}$ \\
Moisture density & $16.11 \pm 1.49^{\mathrm{c}}$ & $17.89 \pm 7.27^{\mathrm{b}}$ & $18.38 \pm 7.34^{\mathrm{a}}$ \\
Bulk density & $4.47 \pm 0.12^{\mathrm{a}}$ & $1.31 \pm 0.28^{\mathrm{b}}$ & $1.38 \pm 0.15^{\mathrm{b}}$ \\
Sand\% & $73.18 \pm 15.76^{\mathrm{b}}$ & $73.42 \pm 15.80^{\mathrm{a}}$ & $73.25 \pm 15.79^{\mathrm{b}}$ \\
$\mathbf{C l a y} \%$ & $3.00 \pm 1.83^{\mathrm{a}}$ & $2.90 \pm 1.95^{\mathrm{a}}$ & $3.08 \pm 1.89^{\mathrm{a}}$ \\
Silt\% & $23.30 \pm 16.15^{\mathrm{b}}$ & $23.75 \pm 16.19^{\mathrm{a}}$ & $23.68 \pm 16.26^{\mathrm{a}}$ \\
$\mathbf{O C} \%$ & $4.80 \pm 2.65^{\mathrm{a}}$ & $3.71 \pm 2.54^{\mathrm{b}}$ & $2.40 \pm 0.29^{\mathrm{c}}$ \\
$\mathbf{O M \%}$ & $8.25 \pm 4.56^{\mathrm{a}}$ & $6.38 \pm 4.6^{\mathrm{b}}$ & $4.12 \pm 1.74^{\mathrm{c}}$ \\
$\mathbf{Z n}\left(\mathbf{m g k g}^{-1}\right)$ & $254.13 \pm 114.33^{\mathrm{c}}$ & $395.43 \pm 144.84^{\mathrm{b}}$ & $444.29 \pm 248.06^{\mathrm{a}}$ \\
$\mathbf{P b}\left(\mathbf{m g k g}^{-1}\right)$ & $154.50 \pm 71.41^{\mathrm{a}}$ & $132.00 \pm 60.70^{\mathrm{b}}$ & $99.94 \pm 31.85^{\mathrm{c}}$ \\
$\mathbf{M n}\left(\mathbf{m g k g}^{-1}\right)$ & $281.06 \pm 72.89^{\mathrm{c}}$ & $364.94 \pm 117.14^{\mathrm{a}}$ & $315.50 \pm 81.13^{\mathrm{b}}$ \\
$\mathbf{C d}\left(\mathbf{m g k g}^{-1}\right)$ & $1.13 \pm 0.88^{\mathrm{c}}$ & $1.38 \pm 1.13^{\mathrm{b}}$ & $1.63 \pm 1.38^{\mathrm{a}}$ \\
\hline
\end{tabular}

of three determination \pm standard deviation size distribution in this study showed that, sand fractions were predominant, while clay was very low in most sites. The clay contents obtained were lower than the report of Dauda and Odoh, (2012). Egharevba and Odjada (2002) reported similar observation of low \% of clay in some soil samples. Soil texture plays an important role in mobility of metals in soil. The textural class for most of the sites were sandy loamy except fuel filling station which was sandy clay and two of the hospital incinerator sites that were loamy sandy. This was similar to the report of Osakwe (2014). Soil organic carbon in dumpsites decreased from $4.80 \pm 2.65 \%$ in depth $0-5$ $\mathrm{cm}$ to $2.40 \pm 0.29 \%$ in depth $10-15 \mathrm{~cm}$ and the mean soil organic matter ranged from $4.12 \pm 1.74 \%$ in depth $10-15 \mathrm{~cm}$ to $8.25 \pm 4.56 \%$ in depth $0-5 \mathrm{~cm}$. Also soil organic carbon in abattoirs decreased with depths with average of $3.27 \pm 2.10 \%$ at $0-5 \mathrm{~cm}$ depth and $1.38 \pm 0.85 \%$ at $10-15 \mathrm{~cm}$ depth. However, mean values of both organic carbon and organic matter across depths were significantly $(\mathrm{p}<0.05)$ different from each other in mechanic workshops. While, organic carbon level of the hospital incinerator soils increased with depth from $2.89 \pm 1.49$ at depth $0-5 \mathrm{~cm}$ to $3.48 \pm 1.52 \%$ at depth $10-15 \mathrm{~cm}$.
Values of soil organic matter and organic carbon content obtained were higher than the control sites. This observation corroborated Oyedele et al. (2008) who reported that polluted sites had significant higher soil organic matter and organic carbon as compared to the control site. Similarly, Ayolagha and Onwugbuta (2001) also demonstrated that organic matter greater than $2.0 \%$ or organic carbon greater than $1.2 \%$ create great conducive medium for heavy metal chelation formation. Sites with relatively high soil organic carbon had higher concentration of heavy metals. Sites with relatively high amount of clay had relatively high organic matter and carbon, this agreed with the report of Quenea $e t$ al. (2009) that clay fraction had highest level of organic carbon and nitrogen. The decline in soil organic carbon in the control sites (lawn and forest) may be as a result of leaching problem that may be attributed to the relatively high sand content. 
Table 3: Physicochemical parameters and heavy metal levels of soil samples from selected abattoirs at different depths.

\begin{tabular}{lccc}
\hline Depth(cm) & $\mathbf{0 - 5}$ & $\mathbf{5 - 1 0}$ & $\mathbf{1 0 - 1 5}$ \\
\hline pH & $6.65 \pm 0.98^{\mathrm{a}}$ & $6.87 \pm 0.47^{\mathrm{a}}$ & $6.74 \pm 0.74^{\mathrm{a}}$ \\
Moisture content & $21.89 \pm 7.65^{\mathrm{a}}$ & $17.61 \pm 4.07^{\mathrm{c}}$ & $19.50 \pm 6.62^{\mathrm{b}}$ \\
Bulk density & $1.16 \pm 0.30^{\mathrm{c}}$ & $1.42 \pm 0.33^{\mathrm{b}}$ & $1.81 \pm 0.37^{\mathrm{a}}$ \\
Sand\% & $64.55 \pm 10.48^{\mathrm{a}}$ & $64.33 \pm 10.05^{\mathrm{b}}$ & $64.22 \pm 10.53^{\mathrm{b}}$ \\
Clay\% & $5.48 \pm 3.89^{\mathrm{b}}$ & $5.65 \pm 3.73^{\mathrm{b}}$ & $6.50 \pm 3.49^{\mathrm{a}}$ \\
Silt\% & $29.98 \pm 10.63^{\mathrm{a}}$ & $20.08 \pm 10.66^{\mathrm{c}}$ & $29.03 \pm 10.98^{\mathrm{b}}$ \\
$\mathbf{O C} \%$ & $3.27 \pm 2.10^{\mathrm{a}}$ & $2.70 \pm 2.41^{\mathrm{b}}$ & $1.38 \pm 0.85^{\mathrm{c}}$ \\
OM\% & $5.63 \pm 3.61^{\mathrm{a}}$ & $4.64 \pm 412^{\mathrm{b}}$ & $2.37 \pm 1.47^{\mathrm{c}}$ \\
$\mathbf{Z n}\left(\mathbf{m g k g} \mathbf{g}^{-1}\right)$ & $632.18 \pm 508.79^{\mathrm{a}}$ & $191.06 \pm 108.97^{\mathrm{b}}$ & $171.93 \pm 82.43^{\mathrm{c}}$ \\
Pb(mgkg & $21.88 \pm 6.72^{\mathrm{a}}$ & $19.75 \pm 6.50^{\mathrm{b}}$ & $19.38 \pm 6.72^{\mathrm{c}}$ \\
Mn(mgkg & $682.44 \pm 143.85^{\mathrm{a}}$ & $697.06 \pm 148.24^{\mathrm{a}}$ & $640 \pm 148.52^{\mathrm{b}}$ \\
Cd(mgkg $\left.^{-1}\right)$ & $0.31 \pm 0.06^{\mathrm{a}}$ & $0.25 \pm 0.02^{\mathrm{a}}$ & $0.25 \pm 0.01^{\mathrm{a}}$ \\
\hline
\end{tabular}

$\mathbf{O C}=$ organic carbon, $\mathbf{O M}=$ organic matter. $; *$ Means with the different superscript along the same row are significantly $(\mathrm{p}<0.05)$ different from each other.; *Each value represents the mean of three determination \pm standard deviation.

Table 4: Physicochemical parameters and heavy metal levels of soil samples from selected fuel filling stations at different depths

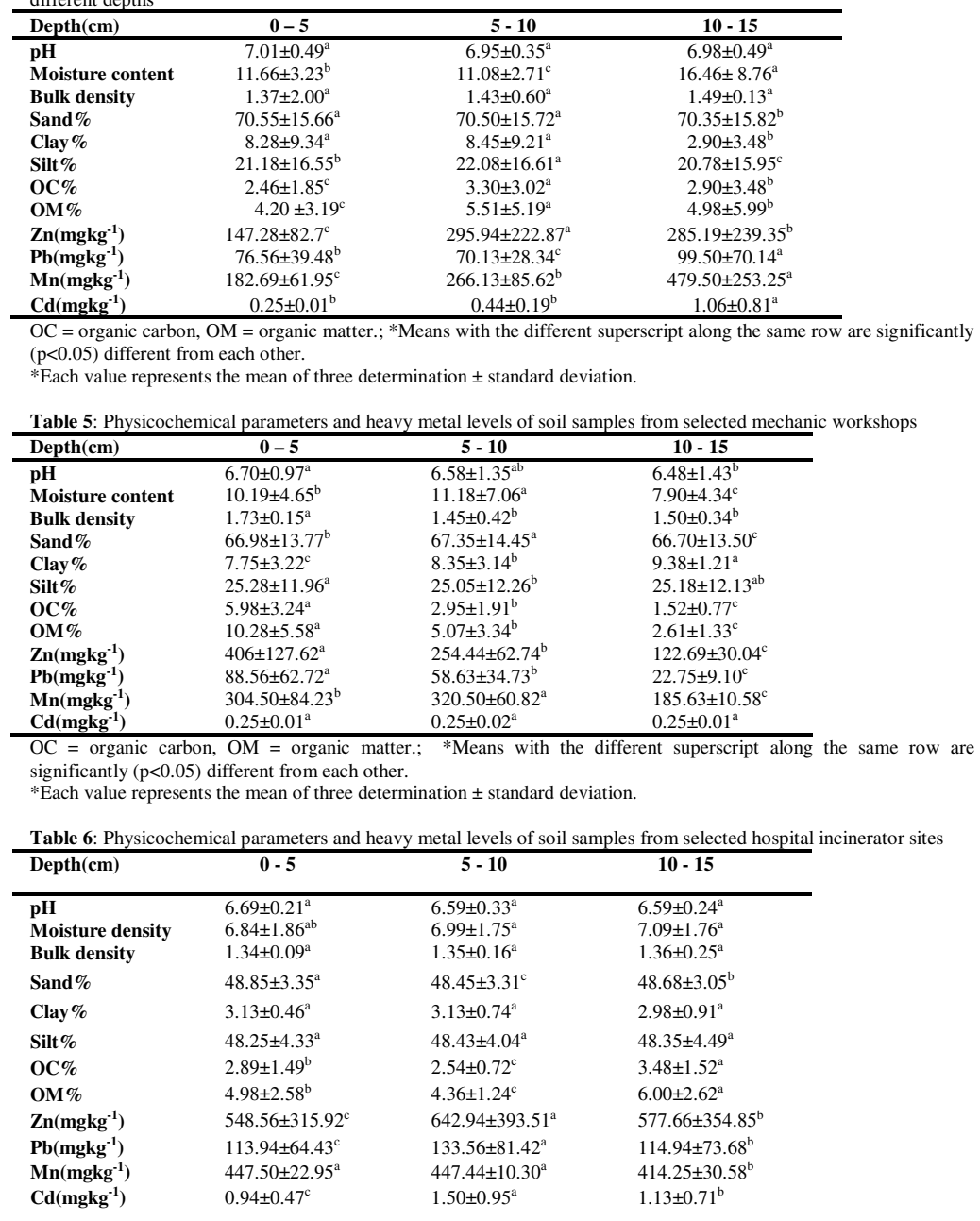

$\mathrm{OC}=$ organic carbon, $\mathrm{OM}=$ organic matter; $*$ Means with the different superscript along the same row are significantly $(\mathrm{p}<0.05)$ different from each other.

*Each value represents the mean of three determination \pm standard deviation.

This is apparent because the clay particles unlike the sand particles have substantial exchange surface areas and therefore adsorb and stabilize organic matter and heavy metals (Dara, 2000). Considering the three soil depths, the highest average soil organic carbon was observed at $0-5 \mathrm{~cm}$ depth, followed by depth $5-10 \mathrm{~cm}$ and lowest at $10-15 \mathrm{~cm}$ depth, hence the soil organic carbon decreasing as the depth increases.
Mean values of organic matter content at dumpsites agreed with Bamgbose et al. (2000).

Heavy metal Concentrations in soil samples from selected locations across the depths:

Mean concentrations of heavy metals of the soil samples are shown in Tables $2-6$. Zinc had highest average concentration across the depths followed by $\mathrm{Mn}$, $\mathrm{Pb}$ and $\mathrm{Cd}$ in dumpsites. Average concentration of $\mathrm{Pb}$, and $\mathrm{Mn}$ decreased with depths, while Zn and $\mathrm{Cd}$ concentrations increased with depth in dumpsites (Table 2). Increase in concentration of manganese in the dumpsites may be attributed to the metal scraps dumped around some of the sites (Idugboe et al., 2014). The concentration of cadmium obtained at dumpsites may be due to the dumping of Poly vinyl chloride (PVC), nickel-cadmium batteries. Concentrations of $\mathrm{Cd}$ obtained at dumpsites and hospital incinerator sites were similar to concentrations reported from soil samples of industrialized environment (Chimezi et al. 2013), dumpsite soil of Markudi (Wuana and Okieimen, 2011), also soils from fuel filling station (Dauda and Odoh, 2012). The highest mean concentration of $\mathrm{Pb}$ was obtained in dumpsites and lowest in abattoir sites. In abattoir the concentrations of $\mathrm{Zn}, \mathrm{Pb}, \mathrm{Mn}$ and $\mathrm{Cd}$ were $632.18 \pm 508.79 \mathrm{mgkg}^{-1}, 21.88 \pm 6.72$ $\mathrm{mgkg}^{-1}, 682.44 \pm 143.85 \mathrm{mgkg}^{-1}$, and $0.31 \pm 0.06 \mathrm{mgkg}^{-1}$ at depth of $0-5 \mathrm{~cm}$ and at $5-10 \mathrm{~cm}$ depth were $191.06 \pm 108.97 \mathrm{mgkg}^{-1}$, $19.75 \pm 6.50 \mathrm{mgkg}^{-}$

${ }^{1}, 697.06 \pm 148.24 \mathrm{mgkg}^{-1}$, and $0.25 \pm 0.02 \mathrm{mgkg}^{-1}$ while at $10-15 \mathrm{~cm}$ depth were $171.93 \pm 82.43 \mathrm{mgkg}^{-}$ ${ }^{1}, 19.38 \pm 6.72 \mathrm{mgkg}^{-1}$, $640.00 \pm 148.52 \quad \mathrm{mgkg}^{-1}$ and $0.25 \pm 0.01$ respectively (Table 3 ).

Relative abundance patterns of the metals at all depths were in the order $\mathrm{Mn}>\mathrm{Zn}>\mathrm{Pb}>\mathrm{Cd}$ in the abattoir and their mean 
concentrations were significantly different from each other. Concentrations of $\mathrm{Pb}$ at abattoir were lower than concentration reported by Yahaya et al. (2009) while $\mathrm{Zn}$ concentrations were higher. $\mathrm{Pb}$ concentration decreases as the depth increases for most of the sites. Mean concentrations of Mn obtained at abattoirs were slightly higher than concentration reported by Yahaya et al. (2000). Manganese concentration at abattoir may be as result of disposal of rumen which contain green grasses that are still in their early stage of digestion, this contains chlorophyll which contain manganese and iron.
While in fuel filling stations $\mathrm{Mn}$ had highest $\left(479.50 \pm 253.25 \mathrm{mgkg}^{-1}\right)$ concentrations at depth 10$15 \mathrm{~cm}$, while, highest $\left(295.94 \pm 222.87 \mathrm{mgkg}^{-1}\right)$ concentration of $\mathrm{Zn}$ was recorded at $5-10 \mathrm{~cm}$ depth(Table 4). $\mathrm{Zn}$ is the second most abundant in soils around the petrol stations. $\mathrm{Pb}$ concentrations at $0-5 \mathrm{~cm}, 5-10 \mathrm{~cm}$ and $10-15 \mathrm{~cm}$ were $76.56 \pm 39.48$ $\mathrm{mgkg}^{-1}, 70.13 \pm 28.34 \mathrm{mgkg}^{-1}$, and $99.50 \pm 70.14 \mathrm{mgkg}^{-}$ 1 respectively. However, lower levels of $\mathrm{Cd}$ were observed with $0.25 \pm 0.00 \%$ at depth $0-5 \mathrm{~cm}$, $0.44 \pm 0.19 \mathrm{mgkg}^{-1}$ at depth $5-10 \mathrm{~cm}$ and $1.06 \pm 0.18$ $\mathrm{mgkg}^{-1}$ at depth $10-15 \mathrm{~cm}$. The relatively high concentrations of $\mathrm{Mn}$ at fuel filling stations may be attributed to leakages of burning fuels (kerosene and diesel) which contain manganese additive. High $\mathrm{Pb}$ concentration observed at all depths might be due to oil spills or leakage of petrol containing lead additive. $\mathrm{Pb}$ concentrations obtained were lower than the report of Dauda and Odoh (2012) but had the same result for $\mathrm{Zn}$ at depth $0-5 \mathrm{~cm}$ from a similar study. High $\mathrm{Pb}$ concentrations in fuel filling station soil samples could be linked up to automobile tail pipe and the use of tetraethyl lead (IV) as an additive in oil processing. In mechanic workshops $\mathrm{Zn}$ was quite high in concentration at $0-5 \mathrm{~cm}$ depth. The average $\mathrm{Zn}$ concentration at this depth was $406.5 \pm 127.62 \mathrm{mgkg}^{-1}$. It decreased with depth to reflect concentration of $254.44 \pm 62.74 \mathrm{mgkg}^{-1}$ at depth $5-10 \mathrm{~cm}$ and $122.69 \pm 30.04 \mathrm{mgkg}^{-1}$ at depth $10-15 \mathrm{~cm}$. Average $\mathrm{Mn}$ concentration varied between 185.63 \pm 10.58 $\mathrm{mgkg}^{-1}$ to $320.50 \pm 60.82 \mathrm{mgkg}^{-1}$. Average $\mathrm{Pb}$ concentration varied between $22.75 \pm 9.10$ to $88.56 \pm 72.72 \mathrm{mgkg}^{-1}$ and $\mathrm{Cd}$ had lowest concentration of $0.25 \pm 0.00 \mathrm{mgkg}^{-1}$ at all depths (Table 5). Highest concentration of $\mathrm{Pb}$ was obtained at mechanic workshop for all depths studied showing that motor vehicles constitute principal source of $\mathrm{Pb}$. Lead concentration greater than $1.0 \mathrm{mgkg}^{-1}$ is generally indicated a local source of pollution. Presence of lead in mechanic workshop may be due to fall-out of lead from batteries or lead acid accumulators. $\mathrm{Pb}$ is derived mostly from exhausts of vehicles, which it is used in Nigeria as minor additives to gasoline and various auto-lubricants. Low concentrations of $\mathrm{Pb}$ obtained from some of the contaminated sites may be due to gradual decrease in metal concentration which could arise from the fact that the metals were leached away from the site (Ayodele and Modupe, 2007). The concentrations of manganese at mechanic workshop were lower than concentration reported by Eddy et al. (2003) and Osakwe (2014). The high Mn concentrations at mechanical workshop could be attributed to the fact that Mn forms a part of batteries, welding works and spray paintings of the vehicles. The concentration of manganese found in mechanic workshop sites were similar to level of $\mathrm{Mn}$ in soils that received significant impact of crude oil in Nigeria (Iwegbue et al., 2009b). The concentration obtained at fuel filling station may be due to regular discharge of petroleum products around these filling stations (Dauda and Odoh, 2012). The concentration of cadmium at mechanic workshop may be due to disposal of engine oil and some other automobile waste and process of vulcanization around these workshops. It was reported that the cadmium level in car tyres is in the range of $20-90 \mathrm{mgg}^{-1}$ as associated with cadmium contamination in the process of vulcanization (Akpoveta et al., 2010).

\begin{tabular}{|c|c|c|c|c|c|c|}
\hline \multirow[b]{2}{*}{ Depth(cm) } & \multicolumn{2}{|c|}{ FUNAAB Forest (Control 1) } & \multicolumn{4}{|c|}{ FUNAAB Lawn (Control 2) } \\
\hline & $0-5$ & $5-10$ & $10-15$ & $0-5$ & $5-10$ & $10-15$ \\
\hline $\begin{array}{l}\mathrm{pH} \\
\text { Moisture } \\
\text { content }\end{array}$ & $\begin{array}{r}7.68 \pm 0.2^{\mathrm{a}} \\
15.65 \pm 0.9^{\mathrm{a}}\end{array}$ & $\begin{array}{r}7.64 \pm 0.1^{\mathrm{a}} \\
13.02 \pm 1.2^{\mathrm{b}}\end{array}$ & $\begin{array}{r}7.56 \pm 0-30^{\mathrm{a}} \\
12.00 \pm 0.80^{\mathrm{c}}\end{array}$ & $\begin{array}{c}6.93 \pm 0.10^{\mathrm{b}} \\
23.20^{\mathrm{a}}\end{array}$ & $\begin{array}{c}7.39 \pm 0.30^{\mathrm{a}} \\
20.50^{\mathrm{b}}\end{array}$ & $\begin{array}{c}7.28 \pm 0.10^{\mathrm{a}} \\
19.00^{\mathrm{c}}\end{array}$ \\
\hline Bulk density & $1.14 \pm 0.9^{b}$ & $1.45 \pm 0.4^{\mathrm{a}}$ & $1.49 \pm 0.20^{\mathrm{a}}$ & $1.26 \pm 0.20^{\mathrm{a}}$ & $1.36 \pm 0.10^{\mathrm{a}}$ & $1.38 \pm 0.10^{\mathrm{a}}$ \\
\hline Sand $\%$ & $7.90 \pm 2.50^{\mathrm{c}}$ & $75.40 \pm 2.00^{\mathrm{b}}$ & $75.90 \pm 2.10^{\mathrm{a}}$ & $66.70 \pm 1.30^{\mathrm{a}}$ & $66.50 \pm 0.40^{\mathrm{b}}$ & $66.20 \pm 0.09^{\mathrm{c}}$ \\
\hline Clay $\%$ & $3.80 \pm 0.10^{\mathrm{a}}$ & $3.80 \pm 0.10^{\mathrm{a}}$ & $3.50 \pm 0.10^{\mathrm{b}}$ & $5.10 \pm 0.40^{\mathrm{a}}$ & $5.10 \pm 0.10^{\mathrm{a}}$ & $5.00 \pm 0.20^{\mathrm{a}}$ \\
\hline Silt \% & $20.30 \pm 0.50^{\mathrm{c}}$ & $20.80 \pm 0.30^{\mathrm{a}}$ & $20.60 \pm 5.00^{\mathrm{b}}$ & $28.20 \pm 0.40^{\mathrm{b}}$ & $28.40 \pm 0.30^{\mathrm{a}}$ & $5.00 \pm 0.50^{\mathrm{c}}$ \\
\hline $\mathrm{OC} \%$ & $1.68 \pm 0.15^{\mathrm{a}}$ & $1.59 \pm 1.22^{\mathrm{a}}$ & $0.84 \pm 0.95^{\mathrm{b}}$ & $2.47 \pm 1.31^{\mathrm{a}}$ & $1.51 \pm 1.42^{\mathrm{b}}$ & $0.96 \pm 2.01^{\mathrm{c}}$ \\
\hline OM \% & $2.89 \pm 0.32^{\mathrm{a}}$ & $2.73 \pm 2.41^{\mathrm{a}}$ & $1.44 \pm 1.31^{\mathrm{b}}$ & $4.25 \pm 2.51^{\mathrm{a}}$ & $2.60 \pm 2.53^{\mathrm{b}}$ & $1.65 \pm 3.90^{\mathrm{c}}$ \\
\hline $\mathrm{Zn}\left(\mathrm{mgkg}^{-1}\right)$ & $44.50 \pm 12.11^{\mathrm{a}}$ & $30.00 \pm 9.00^{\mathrm{c}}$ & $35.50 \pm 9.50^{\mathrm{b}}$ & $15.00 \pm 0.95^{\mathrm{c}}$ & $19.00 \pm 1.25^{\mathrm{a}}$ & $17.00 \pm 2.11^{\mathrm{b}}$ \\
\hline $\mathrm{Pb}\left(\mathrm{mgkg}^{-1}\right)$ & $0.03 \pm 0.01^{\mathrm{a}}$ & $0.13 \pm 0.01^{\mathrm{a}}$ & $0.03 \pm 0.10^{\mathrm{a}}$ & $7.75 \pm 1.13^{\mathrm{c}}$ & $14.00 \pm 2.00^{\mathrm{b}}$ & $31.00 \pm 2.20^{\mathrm{a}}$ \\
\hline $\operatorname{Mn}\left(\mathrm{mgkg}^{-1}\right)$ & $450.25 \pm 4.02^{\mathrm{c}}$ & $532.75 \pm 1.13^{\mathrm{a}}$ & $500.50 \pm 10.41^{\mathrm{b}}$ & $686.75 \pm 14.21^{\mathrm{a}}$ & $612.50 \pm 20.14^{\mathrm{b}}$ & $600.50 \pm 32.50^{\mathrm{b}}$ \\
\hline $\mathrm{Cd}\left(\mathrm{mgkg}^{-1}\right)$ & $<\mathrm{BDL}$ & $<$ BDL & $<$ BDL & $<$ BDL & $<\mathrm{BDL}$ & $<\mathrm{BDL}$ \\
\hline
\end{tabular}


Zn had highest average concentration of $642.94 \pm 353.51 \mathrm{mgkg}^{-1}$ at depth $5-10 \mathrm{~cm}$ in hospital incinerators. Relative abundance of the metals at all depths was $\mathrm{Zn}>\mathrm{Mn}>\mathrm{Pb}>\mathrm{Cd}$ in hospital incinerators (Table 6). All concentrations obtained from all depths and sites were far higher than control sites. High concentration of zinc was observed at hospital incinerator sites and mechanic workshops corroborated with the report of Quenea et al. (2009). The health implications of elevated level of zinc are well documented (Ubwa et al., 2012) and the enhanced concentrations observed at mechanic workshops may be attributed to the presence of additives (consisting of metals in various proposition) in lubricants used by automobile, for example zinc dithiophosphates (Akpoveta et al., 2010). Similar levels of zinc as obtained in this study were at par with that reported by Eddy et al. (2006). The concentrations of zinc in this study were relatively higher than level reported by Jung, (2008); Qishlaqi et al.(2009); Al-Trabulsy et al. (2013); Iwegbue et al. (2013). Zinc is involved in various metabolic activities of many organisms and is also one of the micronutrients essential for normal plant growth, but its increased level can cause many health disorders. Zinc can interrupt the activity of microorganisms and earthworms, thus retarding the breakdown of organic matter (Greany, 2005). Manganese concentrations at hospital sites were lower than concentrations reported by Sunday and Agbaji (2012) and Iwegbue et al. (2013). High concentration of manganese at the control site may have originated from decomposition of leaves and grasses, since manganese plays important role in chlorophyll production. High concentrations of manganese may result in kidney failure, liver and pancreas malfunction but its optimum concentration is very essential for respiratory enzymes and connective tissues development (Osakwe, 2014). The concentration of cadmium obtained at hospital incinerator sites were higher than concentration reported by Sunday and Agbayi (2012), but were lower than Odoh et al. (2012). The relatively high concentration of the cadmium in hospital incinerator sites may be due to disposal of Poly Vinyl Chloride (PVC) injection syringes (Jarup, 2003). Cadmium concentrations in most of the studied sites were lower than concentrations reported by Davaki et al. (2013) and Iwegbue et al. (2013) but agreed with the findings of Asawalaam and Eke (2006) and Njoku and Ayoka (2007).

Contamination and Pollution index: Contamination and Pollution index (C/PI) showed that dumpsites were slightly polluted with $\mathrm{Pb}, \mathrm{Cd}$ and $\mathrm{Zn}$ to moderate pollution while $\mathrm{Mn}$ showed severe contamination.

\begin{tabular}{lcllll}
\multicolumn{6}{l}{ Table 8: Contamination/Pollution Index of the Metals in the Soil Samples } \\
\cline { 2 - 6 } Sites & Depths & $\mathrm{Pb}$ & $\mathrm{Zn}$ & $\mathrm{Mn}$ & $\mathrm{Cd}$ \\
\hline Dumpsites & $0-5$ & 1.86 & 1.74 & 0.64 & 1.41 \\
& $5-10$ & 1.55 & 2.71 & 0.84 & 1.73 \\
& $10-15$ & 1.18 & 3.04 & 0.72 & 2.04 \\
\hline Abattoirs & $0-5$ & 0.26 & 4.33 & 1.56 & 0.39 \\
& $5-10$ & 0.23 & 1.31 & 1.60 & 0.31 \\
& $10-15$ & 0.23 & 1.95 & 1.46 & 0.70 \\
\hline Petrol & $0-5$ & 0.90 & 2.78 & 0.42 & 0.31 \\
Stations & $5-10$ & 0.38 & 2.03 & 0.61 & 0.55 \\
& $10-15$ & 1.17 & 1.95 & 1.10 & 1.33 \\
\hline Mechanic & $0-5$ & 1.04 & & 0.70 & 0.31 \\
Workshops & $5-10$ & 0.69 & 1.74 & 0.73 & 0.31 \\
& $10-15$ & 0.27 & 0.84 & 0.42 & 0.31 \\
\hline Hospital & $0-5$ & 1.34 & 3.76 & 1.02 & 1.18 \\
Incinerators & $5-10$ & 1.57 & 4.40 & 1.02 & 1.18 \\
& $10-15$ & 1.35 & 3.95 & 0.95 & 1.64 \\
\hline
\end{tabular}

At $0-5 \mathrm{~cm}$, the pollution indices were $1.86,1.74,0.64$ and 1.41 for $\mathrm{Pb}, \mathrm{Zn}, \mathrm{Mn}$ and $\mathrm{Cd}$ respectively (Table 8). Abattoirs were slightly contaminated with $\mathrm{Pb}$, moderately and severely polluted with $\mathrm{Zn}$, slightly polluted with manganese and moderately contaminated with $\mathrm{Cd}$. Fuel filling stations were severely contaminated with $\mathrm{Pb}$ and $\mathrm{Mn}$, slightly polluted with $\mathrm{Cd}$ and moderately polluted with $\mathrm{Zn}$. Mechanic workshops were severely contaminated and slightly polluted with $\mathrm{Pb}$ having $\mathrm{PI}$ of 1.04 at $0-5$ $\mathrm{cm}$ depth and moderately polluted with $\mathrm{Zn}$ having PI of 2.78 at the same depth, severely contaminated with $\mathrm{Mn}$ (0.74) and moderately contaminated with $\mathrm{Cd}$ (0.31). Soil from hospital incinerators were slightly polluted with $\mathrm{Pb}$ having PI ranged from 1.34-1.57 and severely polluted with $\mathrm{Zn}$ having PI ranged from $3.76-4.40$ and slightly polluted with $\operatorname{Mn}(0.95-1.02)$ and $\mathrm{Cd}(1.18-1.64)$ at $0-15 \mathrm{~cm}, 5-10 \mathrm{~cm}$ and $10-15$ $\mathrm{cm}$ depths respectively.

Conclusion: The concentrations of selected metals in the soils studied were generally higher than control sites, indicating some degrees of contamination. At some sites the concentrations were higher than natural ranged concentrations and stipulated values of United State Environmental Protection Agency (USEPA, 2002). Zinc and Manganese were the most abundant heavy metals in the studied sites. It was also observed that increase in $\mathrm{pH}$ decreases the concentration of heavy metals in the soil. Mean concentrations of heavy metals studied in the soil samples at all depths measured from abattoir, dumpsite, petrol station, hospital incinerator, and mechanic workshop were found to be in increasing order as $(\mathrm{Mn}>\mathrm{Zn}>\mathrm{Pb}>\mathrm{Cd}),(\mathrm{Zn}>\mathrm{Mn}>\mathrm{Pb}>\mathrm{Cd})$, $(\mathrm{Mn}>\mathrm{Zn}>\mathrm{Pb}>\mathrm{Cd}),(\mathrm{Mn}>\mathrm{Zn}>\mathrm{Pb}>\mathrm{Cd})$ respectively. The order from abattoir and petrol station followed the same order with control site (Mn $>\mathrm{Zn}>\mathrm{Pb}>\mathrm{Cd}$ ). Heavy metal concentrations had significant difference $(\mathrm{p}<0.05)$ on physical and 
chemical properties of soil determined. Contamination and pollution index showed that all anthropogenic sites were moderately polluted and severely contaminated with heavy metals studied. Therefore, there is need for regular monitoring of these anthropogenic activities in order to forestall the impending health risk from heavy metals.

\section{REFERENCES}

Anderson, SE, Ingram, JSI. 1989. Tropical soil biology and fertility: A handbook of methods. C.A.B. International, Aberystwyth.

Andrade, FA., Al-Qureshi, HA., Hotza. D. 2011. Measuring the plasticity of clays. Applied Clay Science, Elsevier, 51(1):1-7.

Anyakora. C., Nwaeze, K., Awodele. O., Nwadike, C., Arbabi, M., Coker, H, 2011. Concentrations of heavy metals in some pharmaceutical effluents in Lagos, Nigeria. Journal of Environmental Chemistry Ecotoxicology 3(3): 25-31.

Ahmed, H., 2002. Assessment of spatial variability of some physicochemical properties of soils under different elevations and land use systems in the western slopes of Mount Chilalo, Arsi. Alemaya University, Ethiopia.

Akan, JC., Audu, SI., Mohammed, Z., Ogugbuaja, VO., 2013. Assessment of heavy metals, $\mathrm{pH}$, organic matter and organic carbon in roadside soils in Makurdi metropolis, Benue State, Nigeria. Journal of Environmental Protection 4: 618- 628.

Akpoveta, OV., Osakwe, SA., Okoh, BE., Otuya, BO., 2010. Physicochemical characteristics and levels of some heavy metals in soils around metal scrap dumps in some parts of Delta State, Nigeria. Journal of Applied Science Environmental Management 14(4): 57-60.

Al-Trabulsy, HA., Khater, AE., Habbani, FI., 2013. Heavy elements concentrations physicochemical characteristics and natural radionuclides levels along the Saudi coastline of the gulf of Aqaba. Arabian Journal of Chemistry 6: 183-189.

Auta, T., Morenikeji, OA., 2013. Heavy metals concentrations around a hospital and a municipal dumpsite in Ibadan city, south-west Nigeria. Journal of Applied Environmental Management 17(3): 419-422.

Ayodele, RI., Modupe, D., 2008. Heavy metals contamination of topsoil and dispersion in the vicinities of reclaimed autorepair workshops in Iwo, Nigeria. Bullet of Chemical Society Ethiopia, 22(3): 339-348.

Ayolagha, GA., Onwugbata, GC., 2001. Suitability comparison of waste disposal site. $27^{\text {th }}$ Proceedings of the Annual conference of the soil science of Nigeria, November 5-9, University of Calabar.

Bamgbose, O., Odukoya, O., Arowolo, TOA., 2000. Earthworms as bio-indicator of metal pollution in dumpsites of Abeokuta city, Nigeria. International Journal of Tropical Biology and Conservation 48: 229-234.

Benton, J., 2002. Agronomic handbook: Management of crops, soils and their fertility. Philosophical Transactions of Royal Society London, Biological Science 363(1492): 685- 701.

Bouyoucos, GJ., 1962. Hydrometer method improved for making particle size analysis of soils. Agronomy Journal, 54, 464465.
Celik, I., 2005. Land-use effects organic matter and physical properties of soil in a southern Mediterranean highland of Turkey. Soil and Till Research 83: 270-277.

Chimezie, A., Teddy, E., Oghenetega, U., 2013. Heavy metal levels in soil samples from highly industrialized Lagos environment. African Journal of Environmental Science and Technology 7(9): 917-924.

Dara, SS., 2000. A textbook of Environmental chemistry and pollution control New Delhi, S. Chand and company Limited $7^{\text {th }}$ Revised Edition.pp39-42

Dauda, MS., Odoh, R., 2012. Heavy metals assessment of soil in the vicinity of fuel filling station in some selected local government areas of Benue State, Nigeria. Pelagia research library, Der chemica sinica, 3(5):1329-1336.

Dawaki, UM., Dikko, AU., Noma, SS., Aliyu ,U., 2013. Heavy metals and physical and chemical properties of soils in Kano urban agricultural lands. Journal of Basic and Applied Sciences 21(3): 239-246.

Eddy NO., Odoemelem, SA, Mbaba, A., 2006. Elemental composition of soil in some dumpsites. Electro Journal of Environmental, Agriculture and Food Chemistry 9: 1349 1365.

Ekpete, OA., Festus, C., 2013. Heavy metal distribution in soil along Iwofe Rumuolumeni road International Journal of Science and Technology 8: 450- 455.

Egharevba, F., Odjada, V., 2002. The pollution potential and chemical interaction parameter of some agro and industrial wastes on soil, Niger Journal of Basic and Applied Science 11: $177-188$.

Farombi, AG., Adebayo, OR., Oyekanmi, AM., 2013. Impact of petroleum products on the soil around automobile workshops in Osun State. Instifor Gover Ser and Res Journal of Applied Chemistry 4 (1): 13-15.

Ferner, DJ., 2001. Toxicity and Heavy metals. Journal of Medicine 2(5): 1.

Fosmire, GS., 1990. Zinc toxicity. American Journal Clinical Nutrition 51 (2): 225-227.

Garba, ST., Ahmed, I., Akan, JC., Dauda, BA., 2014. Distribution pattern of the heavy metals: $\mathrm{Pb}, \mathrm{Zn}, \mathrm{Cd}$ and $\mathrm{Cu}$ in roadside soils of Maiduguri Metropolis, Borno State Nigeria. International Research Journal of Pure \& Applied Chemistry 4(5): 486-493.

Gebeyaw, TY., 2007. Assessment of soil fertility variation in different land uses and management practices in Maybar watershed, South Wollo zone, North Ethiopia. International Journal of Environmental Bioremediation \& Biodegradation 3(1):15-22.

Hoiberg, DH., 2010. Abeokuta. Encyclopedia Britannica Inc., 27. ISBN 978-1-59339-837-8.

Ibitoye, AA., 2006.Laboratory Manual on Basic Soil Analysis. Foladave Nigeria Limited, 16-36. Ideriah, TJK., Braide, SA., Izonfuo, WAL., Adiukwu, PU., 2007. Heavy metal Contamination of soils along roadsides in Port Harcourt Metropolis, Nigeria. Bulletin of Environmental Contamination and Toxicology 73, 67-70. 
Idugboe, SO., Tawari-Fufeyin, P., Midonu, AA., 2014. Soil pollution in two auto-mechanic villages in Benin City, Nigeria. Journal of Environmental Science, Toxic and Food Technology 8 (1): 9-14.

Iwegbue, CM., Bassey, FI., Tesi, GO., Nwajei, GE., Tsafe, AI., 2013. Assessment of heavy metal contamination in soils around cassava processing mills in sub-urban areas of Delta State, Southern Nigeria. Nigeria Journal of Basic and Applied Science 21(2): 96-104.

Iwegbue, CM., Williams, ES., Isirimah, NO., 2009.Study of heavy metals distribution in soils impacted with crude oil in southern Nigeria. Soil and Sediment Contamination 18:136143.

Jarup, L., 2003. Toxicity of heavy metals and sources in the environment. British Medicine Bulletin 68: 167-182.

Jintao, L., Cuicui, C., Xiuli, S., Yulan, H.. and Zhenhai, L., 2011. Assessment of heavy metal pollution in soil and plants from Dunhua sewage irrigation area. International Journal of Electrochemical Science 6: 5314 - 5324.

Jung, MC., 2008. Heavy metal concentrations in soils and factors affecting metal uptake by plants in the vicinity of a Korean $\mathrm{Cu}-\mathrm{W}$ Mine. Sensor 8: 2413-2423.

Jukna, C., Jukna, V., Suigzdaite, J., 2006. Determination of heavy metals in viscera and muscles of cattle. Bulgarian Journal of Veteran Medicine 9(1): 35-41.

Mbagwu, SC., 2003. Aggregate stability and soil degradation in the tropics: Lecture note,

Department of Soil Science, University of Nigeria, Nsukka, Nigeria. LNS0418022

Mckenzie, N., Coughlan, K., Cresswell, A., 2004. Soil Physical Measurement and Interpretation. CSIRO Publishing Colling.

Momodu, M., Anyakora, C., 2010. Heavy contamination of groundwater; the Surulere case study. Research Journal of Environmental Earth Science 2(1): 29-43.

Njoku, PC.,, Ayoka AO., 2007. Evaluation of heavy metal pollutants from soils at municipal solid waste deposit in Owerri, Imo State, Nigeria. Journal Chemical Society of Nigeria 32(1):57-60.

National Population Commission (NPC) 2006. 'Population Census of the Federal Republic of Nigeria: Analytical Report at the National Level. Abuja: National Population Commission.

Ogbonna, DN., Benjamin, LK., Patrick, OY., 2009. Some physicochemical and heavy metal levels in soils of waste dumpsites in Port Harcourt municipality and Environs. Journal of Applied Science Environmental Management 13(4): 65 - 70.

Onweremadu, EU., 2007. Relative suitabilities of soil groups in relation to waste disposal. Resource Journal of Environmental Science 1:258-263.

Orebiyi, EO., Awomeso, JA., Oyedepo, JA., 2008. Assessment of bacteria pollution of shallow well water in Abeokuta, South western Nigeria. Life Science Journal 5(1): 60-72.

Osakwe, SA., 2014. Heavy metal contamination and physicochemical characteristics of soils from automobile workshops in Abraka, Delta State, Nigeria. International Journal of Natural Science Resources 2(4): 48-58.
Oyedele, DJ., Gasu, MB., Awotoye, OO., 2008. Changes in soil properties and plant uptake of heavy metals on selected municipal solid waste dump sites in Ile-Ife, Nigeria. African Journal of Environmental Science and Technology 3(5):107115 .

Quenea,K., Isabelle, L., Winterton, P., Bermond, A., 2000. Interaction between metals and soil organic matter in various particle size fractions of soil contaminated with waste water. Geoderma Elsevier1:217-223.

Qishlaqi ,A., Moore, F., Forghani, G., 2009. Characteristics of metal pollution in soil under two landuse pattens in the Angouran region NW Iran: a study based on multivariate data analysis. Pub Med 15;172(1): 374-84.

Sunday, M., Agbaji, EB., 2012. The influence of hospital waste dumps and incinerator ash on the receiving environment. Advance in Applied Science Research 3(5):2884- 2889.

Tyler, G., Balsbey-pahlsson, AM., Bongtsson, G., Baath, E., Tranvik, L., 1989. Water, Air and Soil pollution 47: 189.

Ubwa ST., Atoo, GH., Offem, JO., Abah, J., Asemave, K., 2013.Effect of activities at the Gboko abattoir on some physical properties and heavy metals levels of surrounding soil. International Journal of Chemistry 5(1): 201-213.

Underwood EJ, (1977) Trace elements in human and animal nutrition: Academic press, New York, Fourth Edition pp 545.

USEPA (United States Environmental Protection Agency). 2001. Supplemental Guidance for Developing Soil Screening Levels for Superfund Sites. OSWER 9355.4e24. Office of Solid Waste and Emergency Response.

United State Environmental Protection Agency (USEPA) 2002.Biosolids applied to land: Advancing standards and practices. National Research Council, National Academy Press, Washinton. DC. pp 282.

Wakene, N., 2001.Assessment of important physicochemical properties of Dystric Udalf

(Dystric Nitosols) under different management systems in Bako area, western Ethiopia. M.Sc.Thesis Submitted to School of Graduate Studies, Alemaya University, Ethiopia. p93.

World Population Reviewed (WPR)(2015).World populationreviewed.com/countries/nigeria-population/majorcities-in-nigeria. [Accessed February $5^{\text {th }}, 2015$ ].

Wuana, RA., Okieimen, FE., 2011. Heavy metals in contaminated soils: A review of sources, Chemistry, risks and best available strategies for remediation. International Scholar Research Notice 2011: 1-20.

Yahaya, MI., Mohammad, S., Abdullahi, BK., 2009. Seasonal variations of heavy metals concentration in abattoir dumping site soil in Nigeria. Journal Applied Science Environmental Management 13(4): $9-13$. 